DOI: http://dx.doi.org/10.21 10/palo.2016.055

\title{
PALEOLIMNOLOGY OF LAKE HAMOUN (E IRAN): IMPLICATION FOR PAST CLIMATE CHANGES AND POSSIBLE IMPACTS ON HUMAN SETTLEMENTS
}

\author{
MOHAMMAD A. HAMZEH, ${ }^{1}$ MOHAMMAD H. MAHMUDY-GHARAIE, ${ }^{1}$ HAMID ALIZADEH-LAHIJANI, ${ }^{2}$ REZA MOUSSAVI-HARAMI, ${ }^{1}$ \\ MORTEZA DJAMALI, ${ }^{3}$ AND ABDOLMAJID NADERI-BENI ${ }^{2}$ \\ ${ }^{1}$ Ferdowsi University of Mashhad, Department of Geology, Mashhad, Iran \\ ${ }^{2}$ Iranian National Institute for Oceanography and Atmospheric Science (INIOAS), Tehran, Iran \\ ${ }^{3}$ Institut Méditerranéen de Biodiversité et d'Ecologie marine et continentale (IMBE), Marseille, France \\ email:mhmgharaie@um.ac.ir
}

\begin{abstract}
Environmental changes since the late deglaciation are reconstructed from the sediment of Lake Hamoun. Lake Hamoun is located at the border of Iran and Afghanistan where inflowing rivers originate from the drainage basins of SW Hindu Kush Mountains and westernmost Himalaya. The lake has experienced a complex hydrological history during the late Quaternary due to climatic changes. Geochemical, sedimentological, and paleontological proxies as well as geomorphological data were used to investigate environmental changes of the lake. The results demonstrate that since the late glacial, the basin has directly and/or indirectly received its moisture from various climatic systems. During the early Holocene, both the Indian summer monsoon (ISM) and the mid-latitude westerlies (MLW) intensified and consequently the basin received higher precipitation. This interpretation is supported by higher content of total organic matter (mean: 8.2\%), finer-grained sediments with low $\delta^{18} \mathrm{O}$ values (mean: $-3.5 \%$ ), as well as rich fossil content. Lower organic matter content $(<5 \%)$, higher magnetic susceptibility values $\left(5.8-10 \times 10^{-4}\right.$ SI unit), and coarser-grained sediments with no shell fragments support the dominance of an arid environment during the early-mid Holocene. The results of stable isotopes suggest weakening of ISM and intensification of MLW during the mid-late Holocene in the study area, when Bronze Age civilizations emerged in the Sistan Basin. In the late Holocene, lake levels experienced more severe fluctuations due to variations in the MLW. Shifts in settlement areas seen in the archaeological record may thus have been a response to climatic changes.
\end{abstract}

\section{INTRODUCTION}

Since the late glacial, the hydro-climatic regime of interior western central Asia has been under the influence of various atmospheric circulation patterns with different intensities. High pressure cells of the Siberian anti-cyclone from the north, low pressure cells of the Indian summer monsoon (ISM) from the south, and mid latitude westerlies (MLW) govern the regional climate (Ricketts et al. 2001; Chen et al. 2008; Dortch et al. 2013). The complexity of regional climate is intensified when the orography of the region (western Himalayas, Hindu Kush, and Iranian plateau) is taken into account.

A relatively large number of paleoclimate records exist from MLWdominated arid central Asia, Tibet, and Himalaya (Chen et al. 2009; Leroy et al. 2013 and references therein), and ISM-dominated southwest Asia (Fleitmann et al. 2007 and references therein). Furthermore, in recent decades, studies on the late Quaternary climate oscillations in Iran have been documented from lake sediments, peat bogs, cave deposits, and playas that are situated mostly on the western and, to a lesser extent, on the central Iranian Plateau (Krinsley 1970; Van Zeist and Bottema 1977; Bottema 1986; Stevens et al. 2001; Wasylikowa et al. 2006; Djamali et al. 2009; Jones et al. 2011; Sharifi et al. 2015). However, the spatio-temporal paleoclimate records of the eastern Iranian Plateau are still scarce and a gap of paleoclimatic data occurs in eastern and southeastern Iran, Afghanistan, Pakistan, and neighboring mountains.

In the arid environment of East Iran and SW Afghanistan, which is characterized by severe windstorms, long-term droughts and occasional flooding events, the distribution of limited water resources and their hydrology is vital in determining the pattern of human settlement. Lake Hamoun is situated at the heart of this harsh environment and is fed by the Hirmand River originating from the SW Hindu Kush Mountains and the westernmost Himalayas (Whitney 2007). Development of various early Bronze Age civilizations along rivers in southeast Iran and adjacent areas, i.e., Tape Yahya, (Potts et al. 2001), Tal-i Iblis (Sajjadi 1987), and Konar Sandal (Majidzadeh 2003) along the Halil River; Shahdad (Salvatori and Vidale 1982) beside the Shahdad River; and Shahr-i Sukhteh (Tosi 1983) and Mundigak (Ball 1982) ashore Hirmand River attests to past favorable climatic conditions in this region during mid to late Holocene.

In this research, we aimed to reconstruct the paleolimnological history of Lake Hamoun and its link with major hydro-climatic events in the Sistan Basin, East Iran, and its catchment area since the last deglaciation. This investigation includes probable connections of Hindu Kush and NW Himalayas glaciations with the lake history, as well as with archaeological records around the lake.

\section{STUDY AREA}

\section{Geography and Geology}

Lake Hamoun occupies the western lowlands of the Sistan Basin, on the border of Iran and Afghanistan, where a large depression (approximately $18,000 \mathrm{~km}^{2}$ ) exists in the southwest extreme of the Hirmand River's catchment basin (Jux and Kempf 1983) (Fig. 1).

The geological history of the Sistan Basin goes back to the Upper Cretaceous when a compressional depression (average elevation: $500 \mathrm{~m}$ 


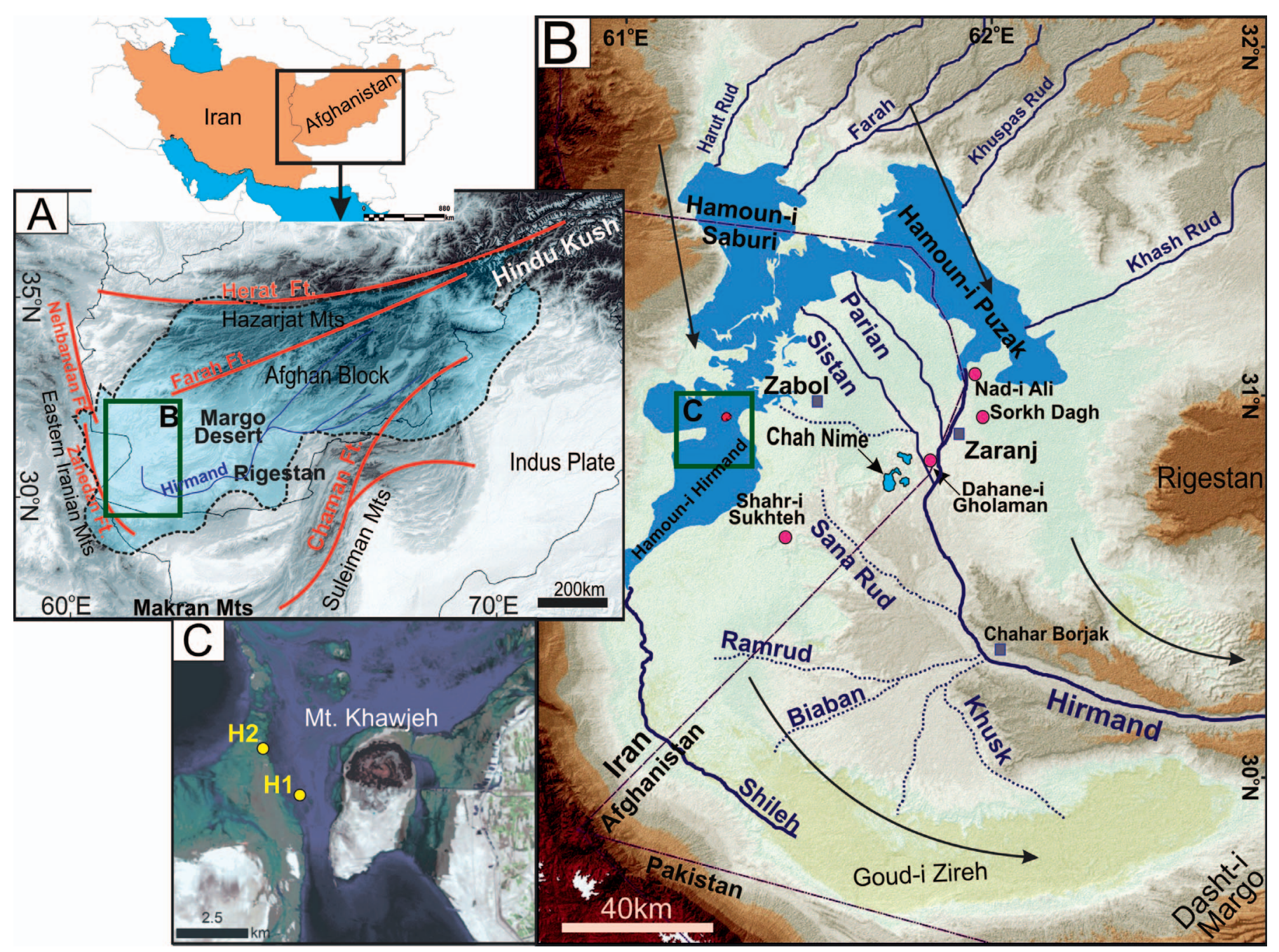

FIG. 1.-A) Topographic map based on 2010 Advanced Space-borne Thermal Emission and Reflection Radiometer (ASTER) digital elevation data showing the study area and dominant geographical and structural features of the Hirmand Basin (transparent area with dashed outline indicates the catchment area of Lake Hamoun). B) Sistan Basin, including Hamoun Lake and its sub-environments and previous, seasonal (dashed line) and modern (solid line) rivers inflowing the lakes. Archaeological sites (red circles) and main towns are also shown. Arrows indicate wind direction. C) Landsat 8 image of the Kuh-i Khawjeh in Hamoun-i Hirmand, showing the two coring sites.

asl) created a local base level for inflowing rivers (Farhoudi et al. 2005) (Fig. 1). The thickness of Neogene and Quaternary sediment in the basin is estimated to reach around $1000 \mathrm{~m}$ (Weippert et al. 1970). The sediment thickness increases westward at the edge of the basin due to active subsidence (Smith 1974). Since the late Tertiary, fluvio-lacustrine sediments have been deposited in the Sistan Basin and its related river valleys. The Sistan Basin has a gentle slope of 1:2500. Geomorphologically, four distinctive features can be distinguished in the Sistan Basin (Fig. 1):

1. Four river terraces, Chahar Borjak ( $520 \mathrm{~m}$ asl), Ramrud (500 m asl), Nimruz (490 $\mathrm{m}$ asl), and Zabol $(480 \mathrm{~m}$ asl), formed as a result of consecutive dry and wet periods (Said-Sajadi 2000). The terraces at higher elevations are older than the lower ones, demonstrating subsidence of depositional base level due to deflation and/or tectonic activity.

2. Dasht-i Margo ("death plain"), a remarkably flat and arid gravel plain partially covered by several active dunes, and the Rigestan ("land of sand"), a desert of inactive dunes (more than $75 \mathrm{~m}$ high) occur in the east with active eolian sand deposits to the west (Fig. 1A). These features are the product of massive wind erosion by northerly and northwesterly, strong wind storms.

3. A $600 \mathrm{~m}$ high, olivine basalt mound (Mollashahi et al. 2011), called Kuh-i Khawjeh, exists inside the lake (Fig.1C).

4. Three sub-basins in the Hamoun lake are the Hamoun-i Puzak (480 $\left.\mathrm{km}^{2}\right)$, the Hamoun-i Saburi $\left(800 \mathrm{~km}^{2}\right)$ and the Hamoun-i Hirmand $(650$ $\mathrm{km}^{2}$ ) (Fig. 1B).

\section{Climate}

The climate of the region is strongly influenced by the sub-tropical high pressure belt that is characterized by continental climate with cold winters and hot summers. The mean annual temperature in the Sistan Basin is 27 ${ }^{\circ} \mathrm{C}$ and freezing temperatures occur from November to March (Whitney 2007). The precipitation regime in the Sistan Basin and its catchment area is also strongly seasonal. The annual precipitation in the catchment basin, mostly in fall and winter, is about $75 \mathrm{~mm}$. That value decreases to $64 \mathrm{~mm}$ in the lake area (Alizadeh-Choobari et al. 2014).

The northerly winds, known as "winds of 120 days" are the most distinctive climatic feature in the study area. These persist from early June to late September, making the Sistan Basin a major source of dust in 
Southwest Asia (Middleton 1986). The winds are related to the northsouth pressure gradient between a persistent cold high-pressure system over the Hindu Kush Mountains in northern Afghanistan and a summertime thermal low-pressure system over the Sistan Basin (Alizadeh-Choobari et al. 2014). In the last two decades of the twentieth century, a prolonged drought over central Afghanistan (Barlow et al. 2002) caused a partial desiccation of Lake Hamoun and, consequently, increased severity and frequency of dust storms.

\section{Hydrology}

Lake Hamoun is a shallow water body with a maximum water depth of 3 $\mathrm{m}$. The lake surface area varies dramatically both seasonally and annually. In dry years, due to a high evaporation rate $\left(>4000 \mathrm{mmyr}^{-1}\right)$, the lake dries up completely and this may last for three to four months (Vekerdy et al. 2006). Maximum lake expansion takes place during late spring, following snowmelt and spring precipitation in the Hindu Kush Mountains. The precipitation over the catchment basin is mainly controlled by the MLW during winter and spring (Whitney 2007). In case of exceptionally high runoff, Lake Hamoun may extend up to $160 \mathrm{~km}$ in length and 8 to 25 $\mathrm{km}$ in width and overflow southward into the normally dry Goud-i Zireh (Fig. 1B), the lowest playa (463 m a.s.l) in the Sistan Basin (Vekerdy et al. 2006).

Hirmand River, Khash Rud, Farah Rud, and Harut Rud are the main rivers discharging into the lake (Fig. 1B). The Hirmand River provides more than $75 \%$ of the inflow. The drainage basin of the Hirmand River is about $170,000 \mathrm{~km}^{2}$, originating in the Hazarjat Range in Afghanistan. The entire catchment area of these four rivers comprises $340,000 \mathrm{~km}^{2}, 51.8 \%$ of the area of Afghanistan (Jux and Kempf 1983) (Fig. 1A). According to data available from 1945 to 1985 , minimal and maximal annual discharge of the Hirmand River ranges between $28.5 \mathrm{~m}^{3} \mathrm{sec}^{-1}$ in 1971 to $467 \mathrm{~m}^{3}$ $\mathrm{sec}^{-1}$ in 1957 (Williams-Sether 2008). Severe droughts, along with dam construction on the Hirmand River by Afghanistan, are the main reasons for dramatically reduced discharge into the lake (Ahlers et al. 2014).

Despite the high evaporation rates, Lake Hamoun is a freshwater reservoir with low concentrations of total dissolved solids. The maximum salinity of water during late summer reaches up to $2.5 \mathrm{PSU}$ and decreases drastically to 0.3 PSU during the spring flooding season (Vekerdy et al. 2006).

\section{METHODS}

\section{Sampling and Sedimentological Analyses}

In September 2013, when the parts of the lake west of Kuh-i Khawjeh were desiccated, we retrieved two sediment cores, 6.2 and $6.8 \mathrm{~m}$-long $\left(30.938^{\circ} \mathrm{N}, 61.215^{\circ} \mathrm{E}\right.$ and $30.949^{\circ} \mathrm{N}, 61.203^{\circ} \mathrm{E}$, respectively) using a $5 \mathrm{~cm}$ diameter Cobra vibro-corer. The distance between the two coring sites is about $1.8 \mathrm{~km}$ (Fig. 1C).

The cores were analyzed for magnetic susceptibility (MS) using a Bartington MS2C sensor with $1-\mathrm{cm}$ resolution, and then were split, visually described, photographed and sub-sampled in the laboratory. Sediment color was determined using Munsell soil color charts (Munsell Charts 2000). A total of 140 sub-samples were analysed for grain-size, total organic matter (TOM) and the fraction of shells. Sampling intervals were based on lithological and MS variations. A FRITSCH Laser Particle Sizer with 62 channels was used to determine grain-size in the range $0.01-$ $1000 \mu \mathrm{m}$ based on Konert and Vandenberghe (1997). Sand, silt, and clay fraction are reported as percentages of siliciclastic fraction in this study.
Loss-on-ignition was used to determine $\mathrm{TOM}$ content $\left(450^{\circ} \mathrm{C}\right.$ at four hours) (Dean 1974). Gastropod and ostracod shells were picked from washed sediments (remaining material in $62 \mu \mathrm{m}$ sieved fraction) from core H1, using a Nikon SMZ 1500 stereomicroscope. Their abundance was calculated per $1 \mathrm{~cm}^{3}$. Relative abundance of plant remains, shell fragments, insect remains and charcoals were also determined using stereomicroscope. The gastropods were identified based on Annandale and Prashad (1919). Ostracod genera were identified based on studies by Griffiths et al. (2001) in SW Iran, and Jux and Kempf (1983) in Lake Hamoun. All of these analyses were performed on both $\mathrm{H} 1$ and $\mathrm{H} 2$ cores in order to correlate them. Because core $\mathrm{H} 1$ is situated in a location appearing to have been less often dry than site H2, based on the higher TOC and shells, analyses on it also include stable isotopes and dating.

Oxygen and carbon stable isotopes were measured at the University of Miami, on 43 calcitic opercula, of the gastropod Bithynia sistanica. Each analysis was performed on one $\sim 1 \times 2 \mathrm{~mm}$ adult operculum, to avoid any problems associated with differences in individual species' vital effects. Only pristine opercula were analyzed, in order to avoid the effects of diagenesis on isotope signature (Keatings and Holmes 2002). Isotope data were corrected for isobaric inferences at mass 45 and 46, and reported relative to Vienna Pee Dee Belemnite (VPDB). Ten duplicate measurements were performed to test accuracy. The $\delta^{13} \mathrm{C}$ and $\delta^{18} \mathrm{O}$ values have a precision of less than $0.1 \%$, as determined by repeated measurement of a standard.

\section{Spatial Data Analysis}

Advanced space borne thermal emission and reflection radiometer (ASTER) sensor data were used to develop a digital elevation model (DEM) of the study area. The DEM was manually classified at selected elevations. Different layers of active and inactive rivers, as well as archaeological sites, were overlaid on DEM using ArcGIS 10.3. We combined the DEM, field measurements on lake terraces as well as previous works of Jux and Kempf (1983) and Said-Sajadi (2000) in order to reconstruct the paleo-shorelines of the lake.

\section{${ }^{14}$ C Dating}

We selected the core $\mathrm{H} 1$ for dating due to its higher \%TOM content. One AMS radiocarbon age was determined on bulk organic matter in Poznan Radiocarbon Laboratory (Lab code: Poz-61477). The ${ }^{14} \mathrm{C}$ age, $11,420 \pm 60$ yrs BP, was calibrated using IntCal 13 (Reimer et al. 2013) to $13,264 \pm 138 \mathrm{cal}$ yrs BP, supporting a late Pleistocene age for the core bottom at $615 \mathrm{~cm}$. Due to low dating resolution, we used linear interpolation to estimate ages between the surface and depth $615 \mathrm{~cm}$. Therefore, in this investigation, we try to attribute a very rough chronology to our sedimentary facies.

\section{RESULT}

\section{Sedimentology}

Cores $\mathrm{H} 1$ and $\mathrm{H} 2$ are correlated based on the identified lithofacies (Fig. 2). Using basic sediment characteristics, the sediments are classified in three main facies: A (including sub-facies A1 and A2), B (including B1 and B2) and $\mathrm{C}$ (including $\mathrm{C} 1, \mathrm{C} 2$ and $\mathrm{C} 3$ ) (Fig. 2). Core $\mathrm{H} 1$ belongs to a more productive environment than $\mathrm{H} 2$. Brown and yellow colors in most parts of core $\mathrm{H} 2$ (sub-units $\mathrm{A} 1$ to $\mathrm{C} 2$ ) suggest subaerial conditions in a playa environment excepting in upper parts (sub-unit C3) where the sediments are

FIG. 2.-Facies descriptions and tentative stratigraphic correlation of cores $\mathrm{H} 1$ and $\mathrm{H} 2$ from Lake Hamoun. The dated horizon is indicated by a star at the bottom of the H1 sequence. The dashed lines between the cores connect similar facies. Schematic image of sedimentary basin corresponding to various facies and some images of core H1 are also shown. 


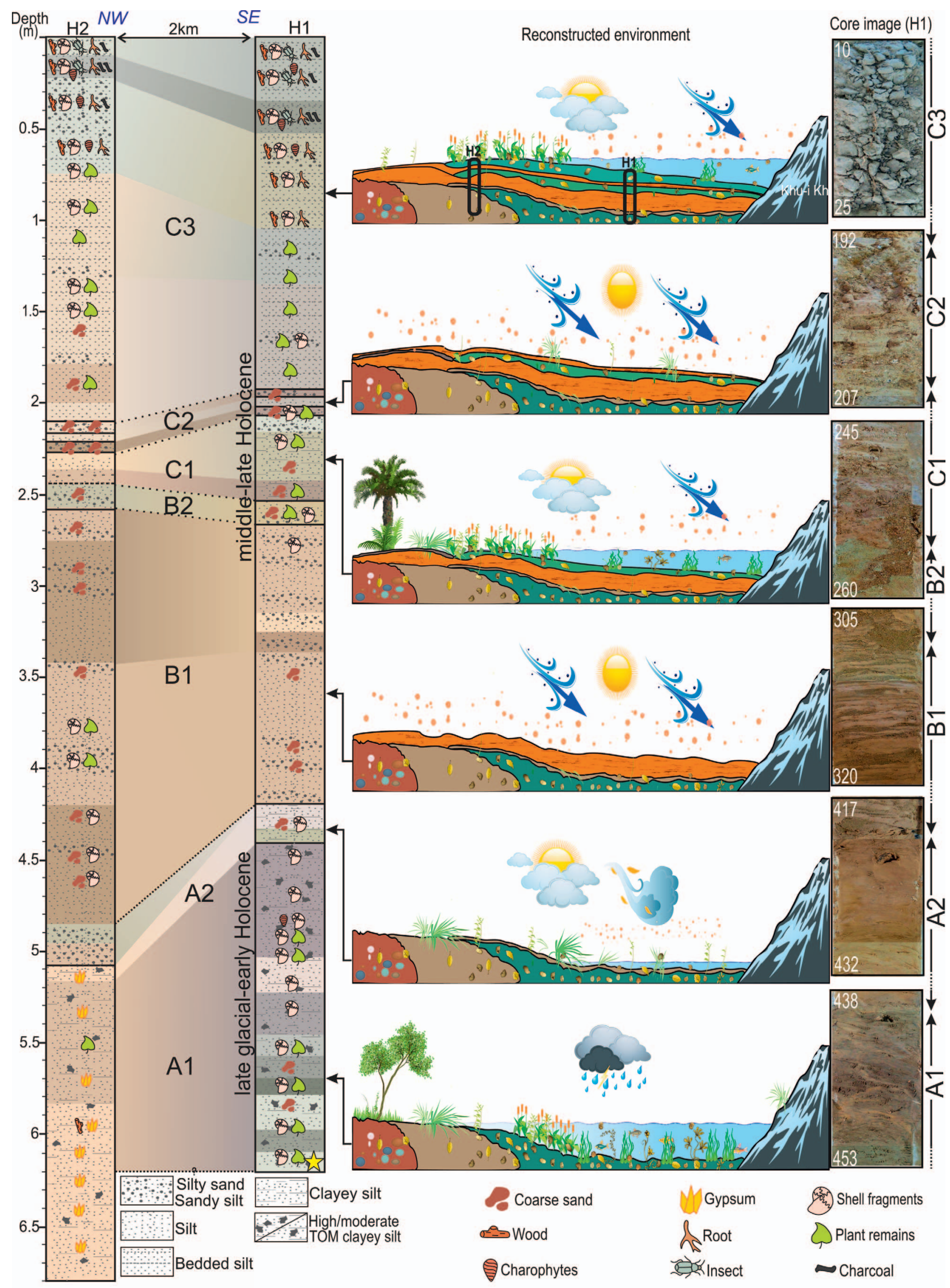


indicative of a relatively shallow lake environment. In contrast, core H1 displays a relatively productive environment dominating almost all along the core, especially in facies A. Cores' lithofacies shows that H1 has thicker deposits of more water-logged facies, indicating that this core site was more lacustrine and had more periods of continuous sedimentation than at $\mathrm{H} 2$. Thus, since $\mathrm{H} 1$ appears to better represent basin-scale hydrological changes, additional sedimentological analyses were performed on it. Facies characteristics of core $\mathrm{H} 1$ are as follows (Figs. 2, 3).

Facies A.-Facies A is characterized by dark massive silt, with a relatively high TOM content (2.3-12.2\%, average: $8.2 \%)$ and low MS values. A dramatic decline in TOM content occurs between 550 and 480 cm (Fig. 3). Based on MS values, facies A has been divided into two subfacies: A1 and A2. MS values range between 3.1 to $4.6 \times 10^{-4}$ SI, for A1 (mean: $3.7 \times 10^{-4} \mathrm{SI}$ ), and 4.9 to $6.3 \times 10^{-4} \mathrm{SI}$ (mean: $5.6 \times 10^{-4} \mathrm{SI}$ ), for A2. Sub-facies A1 with a thickness of $160 \mathrm{~cm}$ is composed of gray, light gray to greenish gray high TOM (decreasing upward) massive clayey silt with abundant shell fragments and plant remains. Sand content in sub-facies A ranges between 0.6 and $27.9 \%$ with an average value of $7.9 \%$. The sand content is relatively high at $560 \mathrm{~cm}$. Mean silt and clay contents are $70 \%$ and 24\%, respectively. The thickness of sub-facies A2 is $40 \mathrm{~cm}$ and a sharp boundary separates it from A2. Its grain size is relatively similar to that of A2. Up-core, pale brown clayey silts of sub-facies A2 changes into sandy silt. The TOM content in A2 is $3 \%$ lower than in A1. In summary, subfacies $\mathrm{A} 1$ and $\mathrm{A} 2$ are indicative of a permanent lake environment with medium to high productivity, and a marsh environment with low productivity, respectively. Correlation of the two cores shows that the TOM content decreases westward and the lacustrine facies in $\mathrm{H} 1$ transition into fine-grained alluvial deposits in $\mathrm{H} 2$.

Facies B.-Very low TOM content $(<5 \%)$, higher MS values $(5.8-$ $\left.10 \times 10^{-4} \mathrm{SI}\right)$ and high sand content differentiate facies B from facies A and C. Facies B has been subdivided in two subfacies: B1 and B2. Sub-facies B1 is $\sim 115 \mathrm{~cm}$ thick, extending from $265-420 \mathrm{~cm}$ deep. An erosional surface marks the contact between sub-facies A2 and B1 at depth $420 \mathrm{~cm}$. This subfacies is composed of about 100 rhythmic intercalations of sandy (eolian) and silty (fluvio-lacustrine) deposits, with a thickness of $<1 \mathrm{~cm}$ to $5 \mathrm{~cm}$ (Hamzeh et al. 2016). Sand content in eolian sand layers and silt content in silty layers reach $55 \%$ and $70 \%$, respectively. There are no shell fragments and plant remains in this sub-facies. The TOM content of silty layers is more than that of sandy layers. In the Munsell color chart, the very pale brown sediments are commonly $10 \mathrm{YR} 7 / 3,7 / 2$, and $8 / 3$. A gradual boundary separates sub-facies B1 and B2 at depth $265 \mathrm{~cm}$. This $10-\mathrm{cm}$ thick layer is composed of pale yellow (2.5Y 7/3) massive silty sand associated with an abrupt increase in MS values. Sand, silt, and clay content in these sediments oscillate between $36-39 \%, 49-50 \%$, and $12-14 \%$, respectively. Generally, facies B represents an arid environment with a dried up lake and seasonal flooding. Sedimentology of sub-facies B2 indicates a transition between an arid environment and a shallow water body. This facies is the same in both cores.

Facies C.-Facies C comprises the upper $255 \mathrm{~cm}$ of core H1. A dramatic decrease in MS values, low sand content (with exceptionally high sand content horizons), decreasing grain size and an increase in TOM content characterize facies $\mathrm{C}$. This facies is subdivided into three subfacies, C1, C2, and C3, based on sediment properties and MS values. Subfacies $\mathrm{C} 1$ (50 $\mathrm{cm}$ thick), from bottom to top, starts with clayey silt, and changes into silt and sandy silt. This coarsening upward of sediments correlates with increasing MS values (from $3.7 \times 10^{-4}$ to $1.1 \times 10^{-3} \mathrm{SI}$ ), decreasing TOM content (from 7.2 to $4.1 \%$ ) and increasing lightness of sediment color (light gray to pale yellow). Ostracod and gastropod shells, and plant remains appear again in this sub-facies. The 10-cm thick sub- facies $\mathrm{C} 2$ consists of two, brown silty sand layers about 3-cm thick, separated by a light gray sandy silt layer. Eolian silty sand layers are composed of $60 \%$ mean sand content, with mean grain size about $165 \mu \mathrm{m}$. The mean TOM content of this sub-facies is $3 \%$, the lowest value in $\mathrm{H} 1$. The lower silty sand layer contains many fragmented reworked carbonate shells (Hamzeh et al. 2016) (57 gastropod and 350 ostracod shells per 1 $\mathrm{cm}^{3}$ ). The most recent sub-facies (C3), present in the upper $195 \mathrm{~cm}$ of $\mathrm{H} 1$, is mostly composed of lacustrine silt with various amounts of sand and clay. The color of its weakly laminated sediments varies from light gray to light greenish gray and greenish gray. At depths 70,120 , and $160 \mathrm{~cm}$, sand content increases dramatically reaching up to $37 \%$. Thus, the range of sand content $(2-37 \%)$ and MS value $\left(8.4 \times 10^{-4}-1.4 \times 10^{-3} \mathrm{SI}\right)$ is wide. Mean TOM content is $7 \%$ with an increasing upward trend. This sub-facies contains many plant remains (charophytes, stems, and roots), shell fragments, and insect remains. Between $35-55 \mathrm{~cm}$ charcoal content increases, as reflected by the darker color of the sediment. In summary, this facies represents a shallow lake environment with frequent lake level changes ( $\mathrm{C} 1$ and $\mathrm{C} 3)$, including a temporary dry period (C2). Lighter and brownish colors in the same facies in core $\mathrm{H} 2$ represent a shallower and exposed environment than that of core H1. Stable Isotopes

Facies B is barren of fossil content, so stable isotopes were only measured for facies A and C. Stable isotope measurements on gastropod opercula show that $\delta^{18} \mathrm{O}$ values range from -8.48 to $3.88 \%$, and $\delta^{13} \mathrm{C}$ values range from -10.84 to $-1.17 \%$ (Fig. 3 , Table 1 ). The $\delta^{18} \mathrm{O}$ values in facies $\mathrm{A}$, and especially sub-facies A1 (-8.48 to $3.88 \%$; mean: $-3.5 \%$ ), are lighter than those in facies $\mathrm{C}(-6.39$ to $2.35 \%$; mean: $-2.71 \%)$. The heaviest $\delta^{18} \mathrm{O}$ value corresponds to the horizon at $580 \mathrm{~cm}$ depth in core $\mathrm{H} 1$. If this value is excluded from the dataset, the average $\delta^{18} \mathrm{O}$ in sub-facies $\mathrm{A} 1$ is $-4.0,1.29 \%$ lighter than that of facies $\mathrm{C}$. Some variations in $\delta^{18} \mathrm{O}$ values occur in facies A and C as single peaks (depths 590, 530, 440, 200, 160,70 , and $30 \mathrm{~cm}$ ), which mostly coincide with higher sand and lower TOM values and fewer B. sistanica and ostracod shells (Fig. 4).

The $\delta^{13} \mathrm{C}$ values in facies $\mathrm{C}$ are $\sim 1 \%$ o lighter than those in facies $\mathrm{A}$. There is an inverse relationship between $\delta^{13} \mathrm{C}$ variations and $\delta^{18} \mathrm{O}$ values and TOM content in facies $\mathrm{A}$; whereas $\delta^{13} \mathrm{C}$ variations do not show a specific trend in facies $\mathrm{C}$.

\section{Paleontology}

Gastropods.-Numerous shells were collected from TOM-rich horizons in facies A and C, in core H1. From a geographical point of view, mollusks in the Sistan Basin are considerably different from the true Eurasian species that occur in central Asia and extend up to the Kashmir Valley (Annandale and Prashad 1919). According to Annandale and Prashad (1919), the mollusks in the Sistan Basin show characteristics of species from the Persian Plateau, referred to as the Afghan-type because of their geographical association. Of the six gastropod species from four different genera (Fig. 4), five are still observed in the modern lake environment. Segmentina calatha is extinct in Lake Hamoun today (Table 2). Variations in gastropod species assemblages reflect favorable living and trophic conditions. Co-occurrence of all gastropod species in facies A along with the highest frequency in the core $\mathrm{H} 1$ shows optimum ecological conditions with permanent shallow lake and abundant freshwater algae and reed development. Peaks in snail abundance occur at depths of 550, 500, and $440 \mathrm{~cm}$, which correlate to $\delta^{18} \mathrm{O}$ variations. Facies $\mathrm{B}$ is characterized by a lack of snail shells. In the uppermost part of the sub-facies B2, as well as in $\mathrm{C} 1$, there are few shells.

In summary, the existence of these species is characteristic of a shallow lake with relatively constant water chemistry and a muddy substrate with dense lake vegetation during the late glacial-early Holocene. This was followed by sparse vegetation cover in late Holocene, fits well with the occurrence of green to brownish green silt to sandy silt lacustrine sediments. 


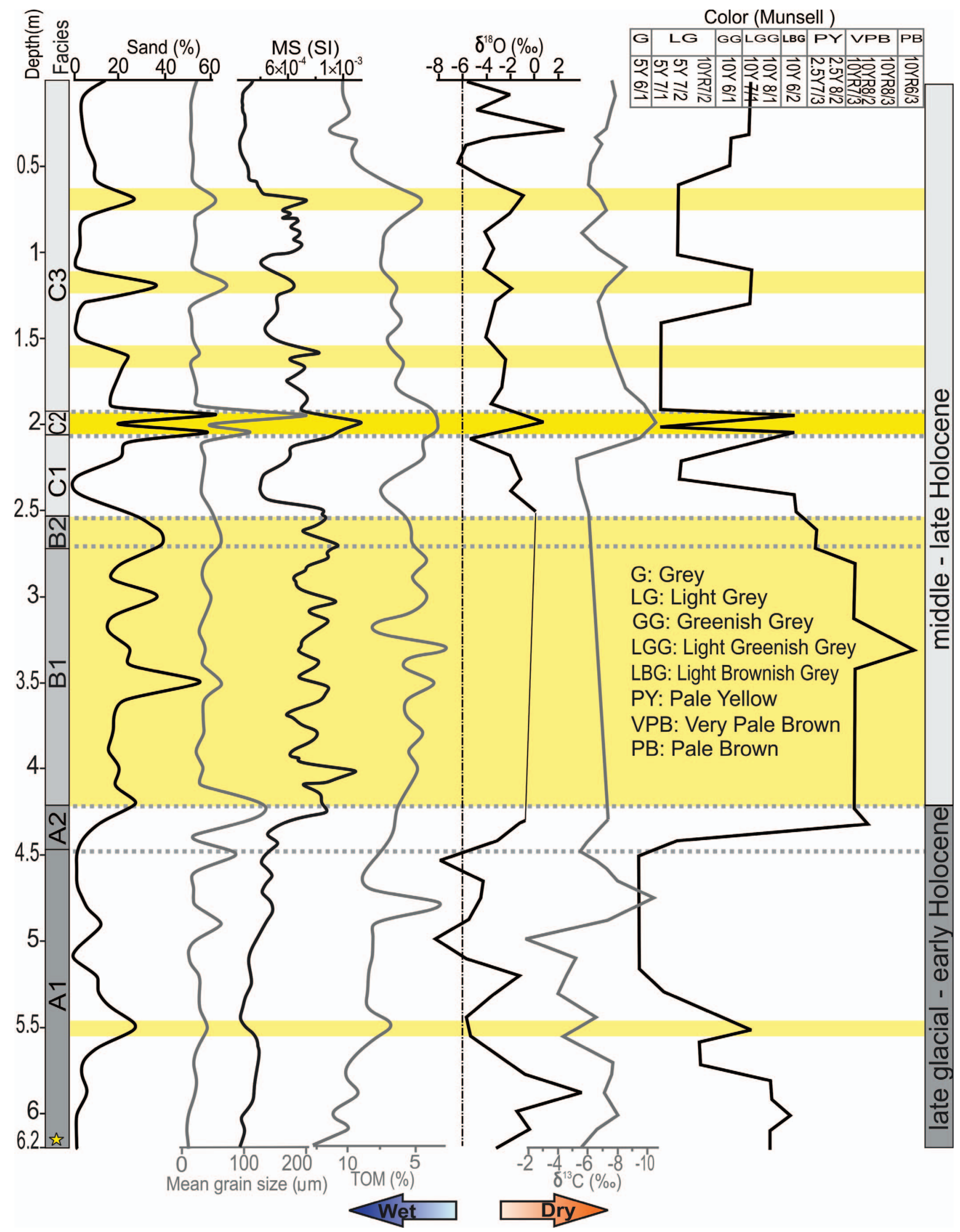


TABLE 1.-Stable isotope (PDB notation) from Bithynia sistanica opercula (Core H1; Lake Hamoun).

\begin{tabular}{lclcc}
\hline \hline Facies & Sub-facies & $\begin{array}{c}\text { Statistical } \\
\text { index }\end{array}$ & $\delta^{18} \mathrm{O}$ value (\%) & $\delta^{13} \mathrm{C}$ value (\%) \\
\hline C & \multirow{2}{*}{ C3 } & Min. & -6.39 & -8.56 \\
& & Max. & 2.35 & -5.63 \\
& & Ave. & -3.14 & -7.11 \\
& & St. Dev. & 2.20 & 0.77 \\
& & Single value & 0.79 & -9.3 \\
& C1 & Min. & -5.36 & -10.8 \\
& C1 & Max. & 0.92 & -3.78 \\
& & Ave. & -1.66 & -6.65 \\
& & St. Dev. & 2.42 & 3.68 \\
A & Single value & 2.67 & -1.02 \\
& A1 & Min. & -8.48 & -10.84 \\
& & Max. & 3.88 & -1.17 \\
& & Ave. & -3.50 & -6.18 \\
& & St. Dev. & 2.95 & 2.63 \\
\hline
\end{tabular}

Ostracods.-Freshwater ostracods, Cypridopsis, Ilyocypris, Cypris, Limnocythere, and Darwinula genera, were found in facies A and C and are shown based on their abundance (Fig. 4). The presence of articulated adult and larval species (excluding sub-facies $\mathrm{C} 2$ ) suggests that these shells were not reworked. In general, these genera occur in shallow freshwater environments (Jux and Kempf 1983) with abundant marsh vegetation and muddy substrates. The frequency of ostracods in core $\mathrm{H} 1$ is positively correlated with snail abundance, especially for B. sistanica (Fig. 4).

\section{DISCUSSION}

Calcareous muds and eolian sands, the main components of the cores, originate from distal Plio-Pleistocene calcareous deposits in the study area (Hamzeh et al. 2016). The high carbonate content and lack of any data on possible reservoir effects make it difficult to assess the accuracy of age data from radiocarbon dating of bulk sediments or shells. The chronology is based on a calibrated age of bulk organic matter at $615 \mathrm{~cm}$ in core $\mathrm{H} 1$ $(13,264 \pm 138)$, assuming a modern core top age $(\sim 0 \mathrm{yr}$ BP). As it is unlikely that sedimentation was truly constant over this interval, these dates should be considered only as estimates and hence, all sequence ages are tentative. The alternation of fluvial, alluvial and eolian sediments suggests the possibility of hiatuses in the sequence, greatly reducing credibility for an age-depth model based only on two ages. The ages given for individual events are thus only rough estimates and are likely to change with an improved chronology.

\section{Paleo-Precipitation Regime}

Opercula from Bithynia have previously been used with success as a material for stable isotope measurements in several paleolimnological studies (Hammarlund et al. 2003; Anadón et al. 2006). $\delta^{18} \mathrm{O}$ variations in opercula calcite depend on $\delta^{18} \mathrm{O}$ of water, calcification temperature and vital effect (Hammarlund et al. 2003). To elucidate any vital effect, we selected B. sistanica as the only target species and analyzed opercula of adults. Considering calculations of Kim and O'Neil (1997) on the impacts of temperature on $\delta^{18} \mathrm{O}$ in calcite formation and findings of Mayewski (2004) on paleo-temperature of the early Holocene, we assume that 0.22 $0.44 \%$ of $1.29 \%$ of the $\delta^{18} \mathrm{O}$ variation between sub-facies $\mathrm{A} 1$ and $\mathrm{C}$ were caused by changes in temperature. In a shallow lake with a very short residence time, like Lake Hamoun (Vekerdy et al. 2006), evaporation over the lake and precipitation in the catchment area are crucial factors influencing $\delta^{18} \mathrm{O}$ values in biogenic carbonate.

The latitude of the Hindu Kush Mountains $\left(35^{\circ} \mathrm{N}\right)$, places the site in an area dominated by winter precipitation with $\delta^{18} \mathrm{O}_{\mathrm{p}}$ influenced mainly by temperature rather than precipitation amount (Araguás-Araguás et al. 1998). According to the global network of isotopes in precipitation, the average $\delta^{18} \mathrm{O}_{\mathrm{p}}$ value for Kabul (Karizimir station) is $-6.01 \%$ (IAEA 1992). Most of the Hamoun $\delta^{18} \mathrm{O}$ values and all of the facies means are much heavier (Fig. 3), which supports the important role of evaporation in Lake Hamoun and its watershed area throughout the depositional record. Our results suggest that this characteristic of winter precipitation dominance arose during the late Holocene. During the early Holocene, Hamoun catchment was under the influence of ISM-associated precipitation with much more summertime moisture (Dortch et al. 2013) and consequently lighter $\delta^{18} \mathrm{O}_{\mathrm{p}}$ values (Araguás-Araguás et al. 1998). The radiocarbon age (Fig. 3), and the relatively light mean $\delta^{18} \mathrm{O}$ values in facies A suggest that this facies accumulated during the late glacial-early Holocene when the region was more influenced by ISM (Fleitmann et al. 2007; Fig. 5B, 5C). The $\delta^{18} \mathrm{O}$ results in facies $\mathrm{C}$ are very different and suggestive of winterdominated precipitation (Whitney 2007; Dortch et al. 2013). In order to determine paleo-precipitation regime, we take into account (1) lack of $\delta^{18} \mathrm{O}$ data for facies B, and (2) our low resolution chronology to divide the core into late glacial-early Holocene and mid-late Holocene intervals.

\section{Late Glacial-Early Holocene}

In order to assess the proportions of various atmospheric systems affecting the hydro-climatic regime of the study area since the last deglaciation, we compare our $\delta^{18} \mathrm{O}$ isotope records with proxy data of the ISM and Siberian High (SH) domains (Fig. 5). The early Holocene $\mathrm{TOM} \%$, grain size, and especially $\delta^{18} \mathrm{O}$ records of Lake Hamoun show some variations which may be attributed to ISM oscillations identified by Gupta et al. (2003), and are almost discordant with MLW associated records (Bradbury et al. 1993). In addition, this humid period in the Sistan Basin is likely concurrent with the early Holocene long-term weakening of SH (see Fig. 5A versus 5D), inferred from increases in concentration of $\mathrm{K}^{+}$ in GISP2 ice core (Mayewski et al. 1997). High solar irradiance and weakening and northward migration of territory influenced by the $\mathrm{SH}$ also pushed the ISM domain northward (Mayewski et al. 2004; Parker et al. 2006) affecting Sistan catchment basin.

The early Holocene climate of the area could be related to northward shifting of inter-tropical convergence zone (ITCZ) and monsoon intensification, as indicated in Oman (Fleitmann et al. 2007) and Central Asia (Chen et al. 2009). Given the geographical position of the Sistan Basin, at the northern boundary of the ISM domain, it is reasonable to consider that the ISM may have had increased influence on climatic conditions of E Iran in the late glacial-early Holocene. This conclusion is supported by the $\delta^{18} \mathrm{O}$ results for facies A, which average $1.29 \%$ lighter than those of facies $\mathrm{C}$ and other factors in both cores indicating a humid and productive environment. In addition, as some research shows, the MLW was active during this time in the northern parts of the ISM domain, such as the northern regions of the Red Sea (Arz et al. 2003), northwestern Arabia (Schulz and Whitney 1987) and northwestern Iran (Sharifi et al. 2015). Consequently, the early Holocene is characterized by ISM and MLW associated moisture, causing the Sistan Basin to experience a more humid condition.

FIG. 3.-Variations in some sedimentological characteristics and stable isotopes in core H1. Yellow bands indicate the periods with frequent dust storms (high sand content). Horizontal dashed lines separate sub-facies. Vertical dashed line in the $\delta^{18} \mathrm{O}$ curve shows the $\delta^{18} \mathrm{O}_{\mathrm{p}}$ value for IAEA/WMO station of Kabul. All curves show moisture decrease from left to right. 


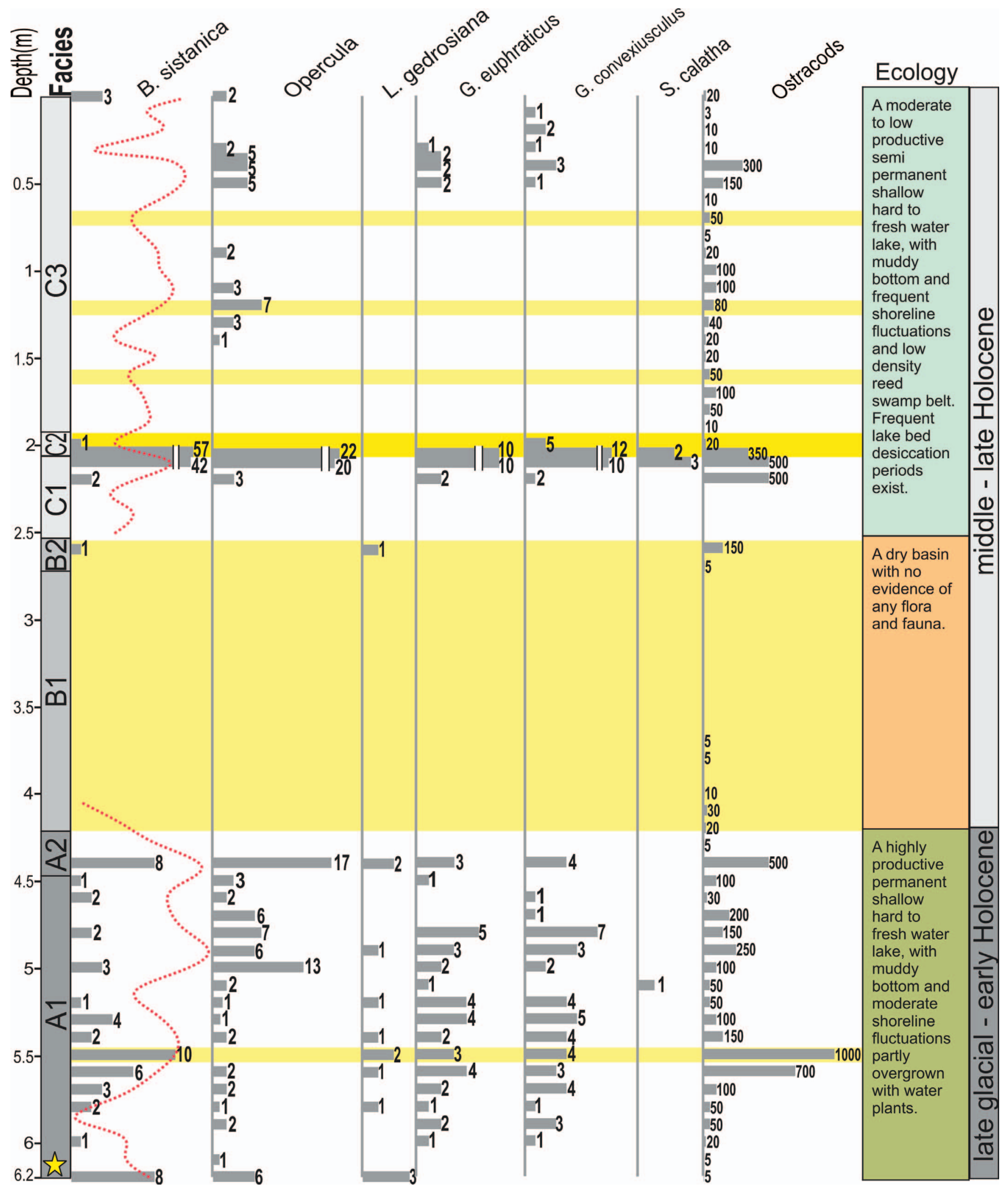

FIG. 4.- Concentration of gastropod species and ostracod types, represented by gray bars, in core H1 (per $\left.\mathrm{cm}^{3}\right)$. A brief paleoenvironmental interpretation for each facies is also shown. Dashed line show variations of $\delta^{18} \mathrm{O}$ for comparison. 
TABLE 2.-Gastropod species in H1 core in Lake Hamoun and their interpreted environments (Annandale and Prashad 1919).

\begin{tabular}{|c|c|c|}
\hline Gastropod species & Assemblage community & Interpreted environment \\
\hline Bithynia sistanica & Dense Phragmites & $\begin{array}{l}\text { Perish annually after floods and the majority of those that survive probably burrow into } \\
\text { the mud and hibernate in winter. Together with almond-shaped operculum }\end{array}$ \\
\hline Lymnaea gedrosiana & Dense Phragmites, Potamogeton pectinatus & Small pools in canebrakes \\
\hline Gyraulus convexiusculus & Lower density Phragmites, Weeds & Water-channels and pools and in the reed beds in Hamoun \\
\hline Gyraulus euphraticus & Lower density Phragmites, Weeds & Shallow freshwater and hard water with more or less marsh vegetation \\
\hline Segmentina calatha & decaying plant material, leaf litter & Swamps, ponds, lakes on decaying plant material and leaf litter \\
\hline
\end{tabular}

\section{Mid-Late Holocene}

The decrease in humidity, inferred from changes between sub-facies A1 and A2, could arise from strengthening of the $\mathrm{SH}$, dominance of the MLW and southward withdrawal of the ISM. A similar scenario is suggested to explain dolomite abundance in Arabian Sea sediments (Fig. 5B, 5C versus 5D) (Sirocko et al. 1993). Evidence of MLW-associated winter precipitation during this period of time was found in lake sediments of Zagros Mountains, west of Iran (Jones et al. 2011).

A sharp change in sedimentological properties occurred at the transition from facies $\mathrm{B}$ to sub-facies $\mathrm{C} 1$, interpreted as a change from dry to more humid conditions, forming a permanent lake in the Sistan Basin. The $\delta^{18} \mathrm{O}$ results in the $\mathrm{C} 1$ facies may be correlated with the findings of Sirocko et al. (1993) corresponding to mid-Holocene, when the ISM seems to have intensified (Fig. 5B), perhaps as a result of weakening of the SH and MLW (Fig. 5D). If so, however, the intensification of the ISM was not sufficiently dynamic to prevent the MLW and SH influence on the region (Fig. 5). The mid-Holocene climate in SE Iran was suitable to the rise of early Bronze Age civilizations, such as Shahr-i Sukhteh, Bampur, Shahdad, Konar Sandal, Tal-i Iblis, and Tappe Yahya (Lamberg-Karlovsky 1968) (Figs. 5, $6 \mathrm{~A})$. Comparison of our $\delta^{18} \mathrm{O}$ record and tentative age model with those from other regions (Mayewski et al. 2004) indicates that dry condition during the well known $4.2 \mathrm{k}$ event over the region, may have been reflected in facies $\mathrm{C} 2$. However, subsequent higher resolution dating is needed to confirm this hypothesis. This phase of intense aridity, well documented across the Middle East (Bond et al. 1997), North Africa, and the Arabian Sea (Staubwasser et al. 2003), is attributed to a strengthening of the MLW. It also corresponds to a drop in the water level of the Caspian Sea (Leroy et al. 2013, 2014).

Our results suggest that the late Holocene in the Sistan Basin (facies C3) was characterized by frequent changes in MLW (Bradbury et al. 1993) and SH activity (Fig. 5A versus 5D). Our $\delta^{18} \mathrm{O}$ record shows five distinct events within what we infer to be of late Holocene age. Periods of prolonged droughts are indicated in proxy records of NW Iran such as Lake Zeribar (Stevens et al. 2001) and Lake Neor (Sharifi et al. 2015), presumably consistent with high $\delta^{18} \mathrm{O}$ values in our record. It is possible that weakening of ISM, along with distal influences of the MLW during the late Holocene exposed the Lake Hamoun basin to frequent droughts. Comparison of our record with local history indicates that historical settlements of Persian empires may have evolved during the humid intervals in late Holocene.

\section{Paleo-Productivity}

The carbon isotopic composition of gastropod shells and opercula is mainly dependent on the composition of the dissolved inorganic carbon (DIC) (Leng 2006). In turn, the composition of DIC depends on the chemical properties of water discharging into the lake, vapor exchange, and lake productivity (Ito 2001). Since the isotopic composition of carbon in calcitic opercula reflects the ${ }^{13} \mathrm{C}$ contents of the lake water during the growing period of the mollusk (Anadon et al. 2006), the $\delta^{13} \mathrm{C}$ content of the DIC in our study reflects the ${ }^{13} \mathrm{C}$ contents of Lake Hamoun during summer (May-August). Variations in the types and area of vegetation cover (proportion of $\mathrm{C} 3$ versus C4 plants) of the Hindu Kush highlands will both affect the composition of the DIC flowing into Lake Hamoun (Vekerdy et al. 2006). The relatively long-term constant trend in the composition of $\delta^{13} \mathrm{C}$ through the core $\mathrm{H} 1$ indicates that proportions of $\mathrm{C} 3$ forest vegetation and $\mathrm{C} 4$ grasses in ever cold high elevations of Hindu Kush have not changed notably. This statement is supported by findings of Pias (1974).

Photosynthesizing organisms preferentially take up ${ }^{12} \mathrm{C}$, leaving surface water DIC relatively enriched in ${ }^{13} \mathrm{C}$ (McKenzie 1985). In the Hamoun shallow lake basin (during middle to late Holocene), because of oxic bottom water, much of the remaining organic matter decomposed in bottom water. This enriched the DIC of the bottom water with ${ }^{12} \mathrm{C}$. Hence, any increase in surface water productivity in the lake led to a decrease of $\delta^{13} \mathrm{C}$ content of the oxic bottom water (Ricketts et al. 2001). In the deep lake (during early Holocene), much of the organic matter decomposed prior to settling to the lake floor thus returning ${ }^{12} \mathrm{C}$ rich organic matter into the water column. The $\delta^{13} \mathrm{C}$ values in facies $\mathrm{A}$ are heavier than those in facies $\mathrm{C}$ and an inverse relationship could be considered for TOM content and $\delta^{18} \mathrm{O}$ with $\delta^{13} \mathrm{C}$ in facies A (Fig. 3, Table 1); corroborating that during the early Holocene, the lake was deep enough to decompose organic matter in the water, column preventing $\delta^{12} \mathrm{C}$ increase of the bottom water. During the late Holocene, no reasonable relationship can be found between $\delta^{13} \mathrm{C}$ values and other parameters, which points to dominance of a shallow, mixed lake.

\section{NW Himalayas Glaciations and Lake Hamoun Hydrological Variations}

Only scarce and often unreliable proxy data about Holocene hydroclimatic variations in the Hindu Kush region are available. A brief paleontological study of west Hindu Kush showed some late Quaternary alternating humid (travertine deposits) and dry (gravel deposits) periods in Band-i Amir valley in the catchment basin of Lake Hamoun (Fig. 6; Jux and Kempf 1971). However, the low-resolution data and uncertainty in age hinders a comparison with our records.

Using new ${ }^{10} \mathrm{Be}$ dating, combined with 645 recalculated ${ }^{10} \mathrm{Be}$ ages from previous studies, Dortch et al. (2013) found some glacial stages in the dry lands of NW Himalayas close to the Hindu Kush, termed semi-arid western Himalayan-Tibetan stages (SWHTS). They suggested that during different periods of the late Quaternary, the SWHTS (Fig. 6) reflects the influence of precipitation from both ISM and/or MLW sources but in varying amounts. During an ISM-related glacial phase, high precipitation and positive mass balance of glaciers caused high run-off from the mountains, while during a MLW-related glaciation phase, lower precipitation over mountains is retained within the glacial ice due to low temperatures.

Glacial stages in Chitral, Himalaya and some other ISM-associated SWHTS took place during the early Holocene (Owen and Dortch 2014) (Fig. 6B). These glacial expansions in NW Himalayas, due to higher precipitation, are presumably correlated with facies A's lighter $\delta^{18} \mathrm{O}$ values, and other evidence of a productive shallow lake environment. Expansion of lakes at this time is synchronous with humid conditions in the Hindu Kush Mountains (Jux and Kempf 1971). 


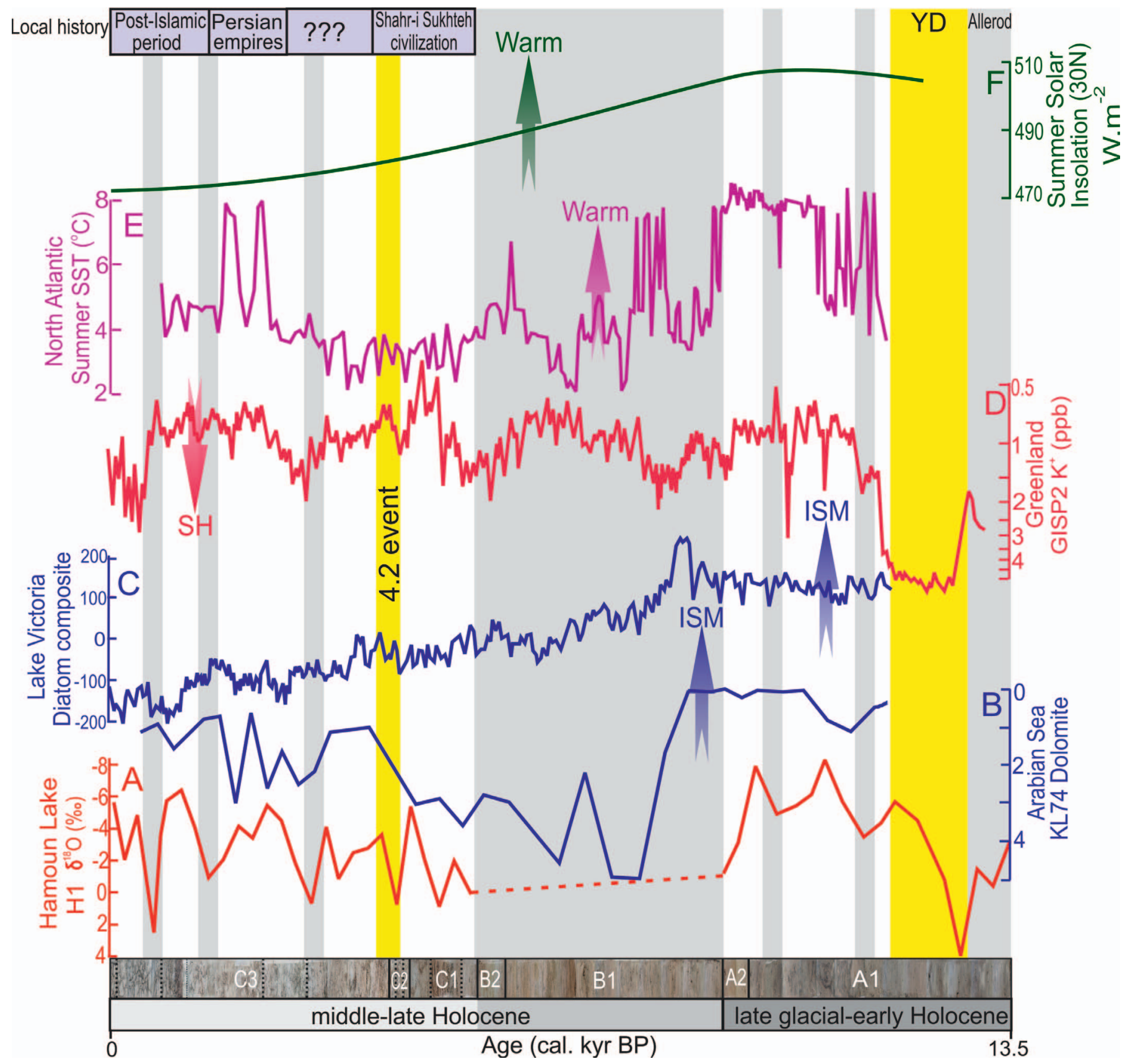

FIg. 5. - Image of core $\mathrm{H} 1$ from Lake Hamoun, and its $\delta^{18} \mathrm{O}$ record of opercula B. sistanica (A). Records are also compared with local historical periods. Light bands show short term and long-term dry periods of Hamoun for comparison; dolomite abundance (\%) in core KL74 from the Arabian Sea (Sirocko et al. 1993) (B), and P:E or lake level proxy based on calibration of a diatom ratio, Lake Victoria (Mayewski et al. 2004) (C) as proxy of ISM change; variations in $\mathrm{K}^{+}$ion concentration from GISP2 ice core as a proxy for changes in the strength of the Siberian Anticyclone (Mayewski et al. 1997) (D); summer sea surface temperatures $\left({ }^{\circ} \mathrm{C}\right.$ ) for the North Atlantic from a planktonic foraminiferal modern analogue function (Mayewski et al. 2004) (E); summer solar insolation ( $\mathrm{Wm}^{-2}$ ) at $30^{\circ} \mathrm{N}$ (Berger and Loutre 1991) (F). Arrows on every diagram show the direction of increasing strength of each parameter.

Dry conditions recorded in facies B may be correlated with the evolution of MLW-associated SWHTS in central Asia and Himalaya, such as K2, Hunza, and Nanga Parbat (Fig. 6B) (Dortch et al. 2013). According to Dortch et al. (2013), late Holocene SWHTS are broadly correlated with northern hemisphere climatic events. However, due to low-resolution proxy records of western Himalayas during the late Holocene, it is difficult to correlate paleo-glaciation phases with paleohydrological conditions in the Hamoun sequence. In addition, sedimentological properties in the studied cores suggest that, during this period, an unstable climate with frequent wet and dry intervals dominated in East Iran, presumably as a result of orbital changes in insolation that affected much of the northern hemisphere (Mayewski et al. 2004).

\section{Paleogeography and Human Occupation}

Fishing tools found in archaeological sites of early Bronze Age and younger ones in Shahr-i Sukhteh (Fig. 1) led Costantini and Tosi (1978) to 


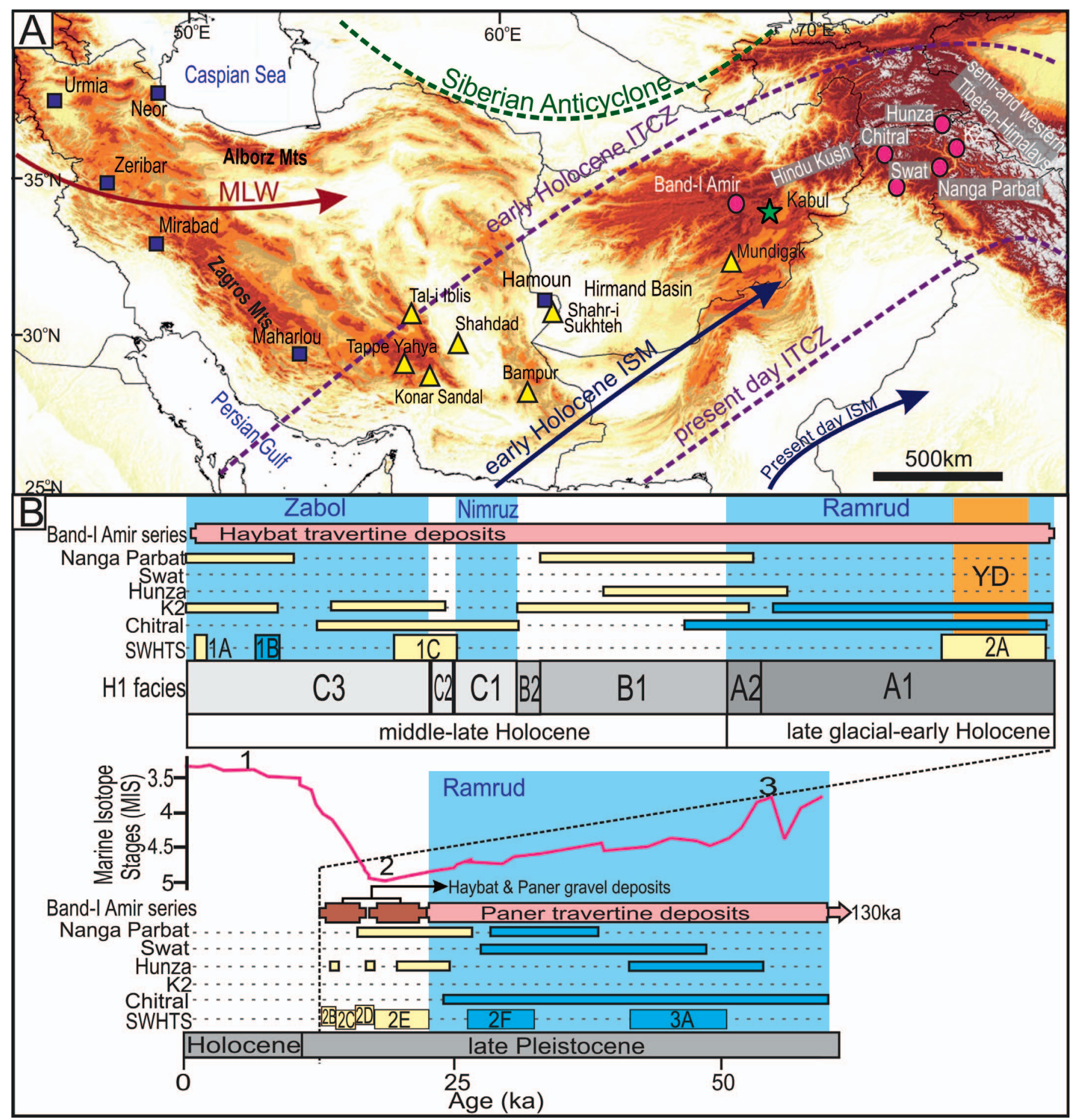

FIg. 6.-A) General map of Iran and Afghanistan with dominant circulation systems of the westerlies (MLW), Indian summer monsoon (ISM) and Siberian Anticyclone, glaciers of semi-arid western Himalayas and Hindu Kush (circles), Bronze Age archaeological sites of SE Iran (triangles) and lakes of W Iran (squares). Proposed early Holocene ITCZ position is also shown. B) Age plot of semi-arid western Himalaya-Tibetan Stages (SWHTS) for the semi-arid regions at the western end of the HimalayanTibetan orogeny defined by Dortch et al. (2013) and glaciations in some neighboring elevations consist of Chitral, central Karakoram (K2), swat valley, Hunza, and Nanga Parbat (Owen and Dortch 2014). ISM-associated and MLW-associated glacial stages are shown by blue and yellow bars respectively. Band-i Amir travertine lakes are also shown (Jux and Kempf 1971). Lithological facies of core H1 and marine $\delta^{18} \mathrm{O}$ curve (Lisiecki and Raymo 2005) are provided for comparison. Blue shading shows probable intervals of large lake phases in the Sistan Basin. 

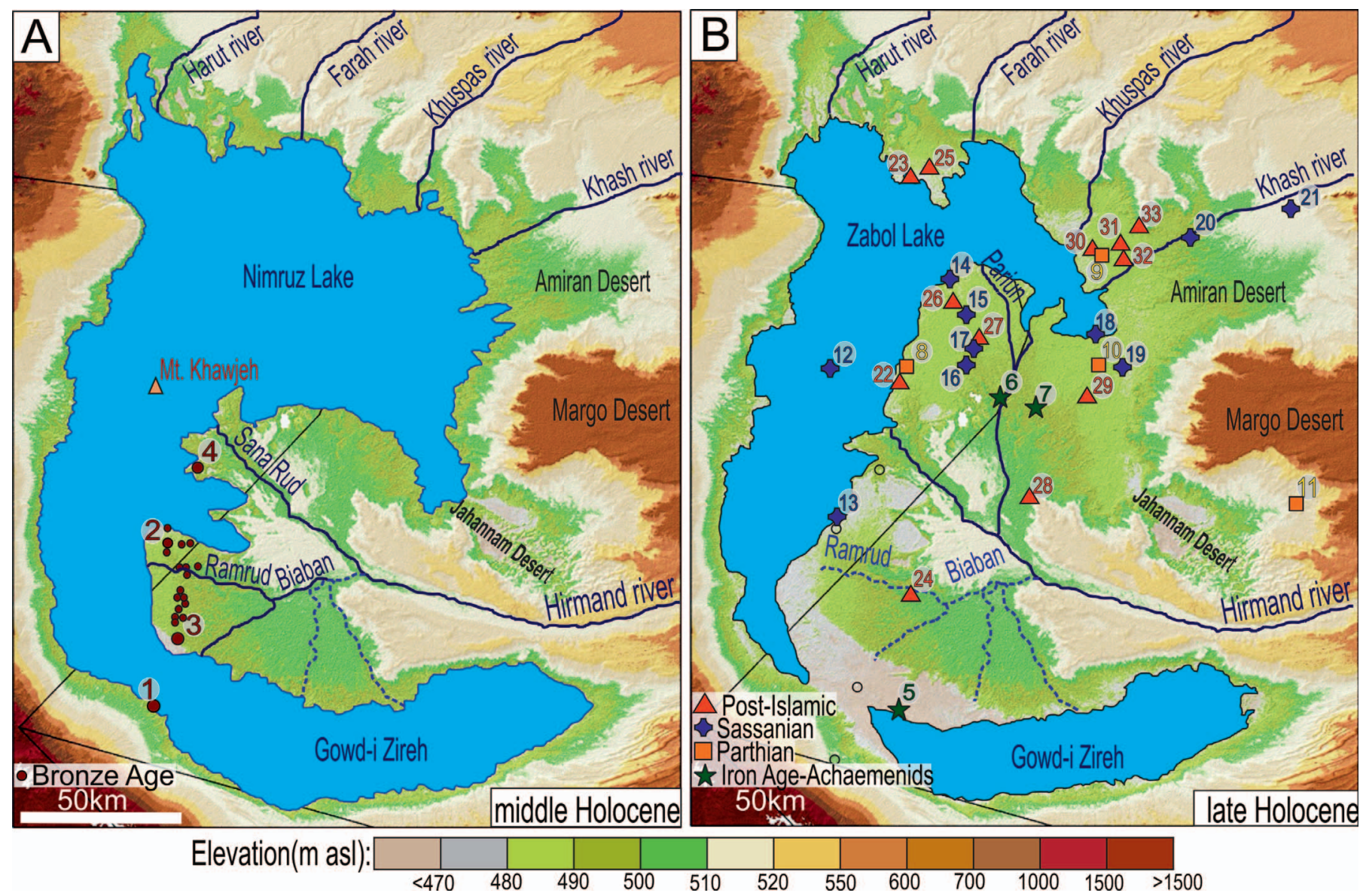

FIG. 7.-ASTER hillshade Global Digital Elevation Model of the Sistan Basin containing lakes maximal expansions during the middle and late Holocene. Solid and dashed lines show active and inactive rivers during particular periods respectively (Fairservis 1961). Archaeological sites corresponding to different historical periods of Bronze Age (4th-2nd millennium BC), Iron Age-Achaemenids (2nd millennium BC-3rd century BC), Parthian (2nd century BC-2nd century AD), Sassanian (2nd century AD-7th century AD) and Post-Islamic (7th century AD) are also shown. 1: Khaima Barang, 2: Akhor-i Asb-i Rostam, 3: Gardan Rig, 4: Shahr-i Sukhteh, 5: Gudar-i Shah, 6: Dahane-i Gholaman, 7: Nad-i Ali, 8: Qal'a-i Sam, 9: Pust-i Gau, 10: Qal a-i Nau, 11: Sar-o Tar, 12: Kuh-i Khawjeh, 13: Howzdar, 14: Borj-i Afghan, 15: Qal a-i Tappeh, 16: Ram Shahrestan, 17: Atashgah, 18: Borj-i Ghunda, 19: Chehel Borj, 20: Nishk, 21:Qal a-i Wabu, 22: Sekuhe, 23:Kul Marut, 24: Tarakun, 25: Peshwaran, 26: Bibi Dust, 27: Zahedan-i Kohne, 28: Qal'a-i Fath, 29: Kurdu, 30: Kharabe-i Idukha, 31: Gul-i Sefid, 32: Diwal-i Khudadad, 33: Khawjeh Nakhi (Fairservis 1961; Ball 1982; Tosi 1983; SaidSajadi 2000; Whitney 2007).

suggest that fishing had a major role in the economy of historical communities in the Sistan Basin. These early societies built their settlement close to their food source on the shorelines of Lake Hamoun. McMahon (1906), Jux and Kempf (1983) and Said-Sajadi (2000) recognized some paleo-shorelines in Hamoun Basin at higher elevations. Among them, we examined mid-late Holocene terrace elevations to reconstruct paleogeography and human occupation using elevation-based, manually classified, DEM images. The age of the past shorelines was assessed based on welldated ancient archaeological sites located on the terrace borders (SaidSajadi 2000), on an ancient chronology of Alpine-Himalayan glaciations (Jux and Kempf 1983). Considering our rough chronology, visualizing paleolake expansions during different time periods of Holocene allow a better understanding of paleolimnology of Lake Hamoun and its effects of ancient settlements.

\section{Nimruz Paleoshoreline}

Development of a shallow lake during the mid-Holocene, presumably corresponding to facies $\mathrm{C} 1$, facilitated the rise of early Bronze Age civilizations in the Sistan Basin (Tosi 1983) (Fig. 7A). Figure 7A shows four excavated and many more unexcavated Bronze Age archaeological sites situated along the reconstructed Nimruz paleoshoreline, close to Rudi Biaban, suggesting lake extension from ca. 6 to $3.8 \mathrm{kyr}$ BP. The earliest known site in the Sistan Basin is Khaima Barang (6 kyr BP), which is located along the lower Shileh River in Afghanistan, and Shahr-i Sukhteh (5.2-3.8 kyr BP) in Iran, both of which were supplied by water coming from the Rud-i Biaban (Fig. 7A; Whitney 2007). No archaeological site has been found in the Afghan part of the Sistan Basin, suggesting that Rudi Biaban was the principal source of freshwater recharge into Lake Hamoun during the late Holocene (Fairservis 1961).

\section{Zabol Paleoshoreline}

The Zabol paleoshoreline extension confirms that the late Holocene lake volume never reached the extents of the early Holocene. This is probably because latter lake phases were fed by high amounts of ISM associated moisture, whereas the late Holocene stage of the lake was predominantly fed by precipitation sourced from the MLW. It seems that while MLWdominated climate made a fragile environment in the Sistan Basin, the area also experienced periodic severe wind storms, droughts and floods, evidenced by the diverse color, sand content, magnetic susceptibility, and TOM values in sub-facies C3. Using grain morphoscopy, Hamzeh et al. 
(2016) concluded that sand fractions in facies B and C have been transported to the basin by wind.

During the period possibly corresponding with facies C3, several human settlements belonging to the pre-Islamic and Islamic eras inhabited the delta of Hirmand River and lake shores (Fig. 7B) (Fairservis 1961). Since $2.5 \mathrm{kyr}$ BP, the region east of Sana Rud and Goud-i Zireh was occupied by Achaemenids. Sassanians (224-651 AD) intensively populated the region and practiced intensive agriculture as well (Fairservis 1961). Flourishing Achaemenids and Sassanian cultures in the south of Iran may have been due to a climatic optimum (Miller et al. 2013). Our results suggest that this period probably coincided with increasing MLW-associated precipitation in the Sistan Basin (Fig. 5A). This idea is corroborated by findings of Djamali et al. (2016) and Sharifi et al. (2015) in central and west of Iran.

\section{CONCLUSIONS}

Although limitations regarding the age of the two cores prevent assessing paleoclimate of SE Iran and human response with high resolution, our paleolimnology results in Lake Hamoun are supported by other climatic records of SW Asia, and show that, since the late deglaciation, Lake Hamoun (East Iran) has experienced a complex hydrological history as a result of fluctuations in the amount and source of moisture from both local and Hindu Kush Mountains. We infer that during the late glacial-early Holocene, the climate was probably governed by the ISM and MLW (to a lesser amount), whereas in the mid to late Holocene it seems that the ISM influence gradually decreased. By the late Holocene, the MLW and SH may have been responsible for a relatively drier and fragile climate over the Sistan Basin. Furthermore, ecological traits of gastropods and ostracods, suggest that a less productive shallow lake with more oxic bottom conditions was likely predominant during the late Holocene. This is due to limited moisture input from the North Atlantic Ocean and its marginal seas (e.g., Mediterranean Sea) by the MLW

Considering our rough chronology, visualizing paleolake expansions during different time periods of Holocene using image processing and GIS, helped to better reconstruct paleolimnology of Lake Hamoun and its effects of ancient settlements.

Lake Hamoun has been the life blood of great Bronze Age and later civilizations in the Sistan Basin, thus a high-resolution chronology is needed to provide a more precise perspective of human-environment interaction in this arid area of East Iran.

\section{ACKNOWLEDGMENTS}

The authors acknowledge M. Baziar for his help during fieldwork and show their appreciation to G. Baskaleh for his support in laboratory work. This study has been supported by the Iranian National Institute for Oceanography and Atmospheric Sciences (INIOAS) in the framework of a project entitled 'Environmental Monitoring and Environmental Forecasting of the Iranian Internal Lakes' (No 391-012-01). The authors also thank editors, reviewers, and Professor Suzanne A. G. Leroy for linguistic and scientific correction of the text.

\section{REFERENCES}

Ahlers, R., Brandimarte, L., Kleemans, I., and Sadat, S.H., 2014, Ambitious development on fragile foundations: criticalities of current large dam construction in Afghanistan: Geoforum, v. 54, p. 49-58

Alizadeh-Choobari, O., Zawar-Reza, P., and Sturman, A., 2014, The "wind of 120 days" and dust storm activity over the Sistan Basin: Atmospheric Research, v. 143, p. $328-341$.

Anadón, P., Moscariello, A., Rodríguez-Lázaro, J., and Filippi, M., 2006, Holocene environmental changes of Lake Geneva (Lac Léman) from stable isotopes $(\delta 13 \mathrm{C}, \delta 18 \mathrm{O})$ and trace element records of ostracod and gastropod carbonates: Journal of Paleolimnology, v. 35, p. 593-616.
Annandale, N. And Prashad, B., 1919, The Mollusca fauna of the inland waters of Baluchistan and of Seistan: Records of the Indian Museum, v. 18, p. 18-62.

Araguás-Araguás, L., Froehlich, K., and Rozanski, K., 1998, Stable isotope composition of precipitation over southeast Asia: Journal of Geophysical Research: Atmospheres (1984-2012), v. 103, p. 28721-28742.

Arz, H.W., Lamy, F., Pätzold, J., Müller, P.J., and Prins, M., 2003, Mediterranean moisture source for an early Holocene humid period in the northern Red Sea: Science, v. 300, p. $118-121$

BaLl, W., 1982, Archaeological Gazetteer of Afghanistan: Catalogue des sites archeologiques d'Afghanistan, sur les Editions Recherches Civilisations, Paris, 2 vols., Asie Centrale, p. 55-57.

Barlow, M., Cullen, H., And Lyon, B., 2002, Drought in central and southwest Asia: la Niña, the warm pool, and Indian Ocean precipitation: Journal of Climate, v. 15, p. 697700.

Berger, A. AND Loutre, M.-F., 1991, Insolation values for the climate of the last 10 million years: Quaternary Science Reviews, v. 10, p. 297-317.

Bond, G., Showers, W., Cheseby, M., Lotti, R., Almasi, P., Priore, P., Cullen, H., Hajdas, I., AND BonANI, G., 1997, A pervasive millennial-scale cycle in North Atlantic Holocene and glacial climates: Science, v. 278, p. 1257-1266.

BotтemA, S., 1986, A late Quaternary pollen diagram from Lake Urmia (northwestern Iran): Review of Palaeobotany and Palynology, v. 47, p. 241-261.

Bradbury, J.P., Dean, W.E., And Anderson, R.Y., 1993, Holocene climatic and limnologic history of the north-central United States as recorded in the varved sediments of Elk Lake, Minnesota: a synthesis: Geological Society of America Special Papers, v. 276, p. 309-328.

CharTs, M.S.C., 2000, Revised washable edition: Gretag Macbeth, New Windsor, NY. Chen, F., Holmes, J., Wünnemann, B., and Yu, Z., 2009, Holocene climate variability in arid Asia: nature and mechanisms: Quaternary International, v. 194, p. 1-5.

Chen, F., Yu, Z., Yang, M., Ito, E., Wang, S., Madsen, D.B., Huang, X., Zhao, Y., Sato, T., Birks, J.B, Boomer, I., Chen, J., An, C., And Wünnemann, B., 2008, Holocene moisture evolution in arid central Asia and its out-of-phase relationship with Asian monsoon history: Quaternary Science Reviews, v. 27, p. 351-364.

Costantini, L. And Tosi, M., 1978, The environment of Southern Sistan in the third millenium BC, and its exploitation by the proto-urban Hilmand civilization, in W.C. Brice (ed.), The Environmental History of the Near and Middle East Since the Last Ice Age: Academic Press, London, p. 165-183.

DEAN, W.E., 1974, Determination of carbonate and organic matter in calcareous sediments and sedimentary rocks by loss on ignition: comparison with other methods: Journal of Sedimentary Research, v. 44, p.242-248.

Duamali, M., de Beaulieu, J.-L., Andrieu-Ponel, V., Berberian, M., Miller, N.F., Gandouin, E., Lahijani, H., Shah-Hosseini, M., Ponel, P., and Salimian, M., 2009, A late Holocene pollen record from Lake Almalou in NW Iran: evidence for changing land-use in relation to some historical events during the last 3700 years: Journal of Archaeological Science, v. 36, p. 1364-1375.

Diamali, M., Jones, M.D., Migliore, J., Balatti, S., Fader, M., Contreras, D., Gondet, S., Hosseini, Z., LahiJani, H., and Naderi, A., 2016, Olive cultivation in the heart of the Persian Achaemenid Empire: new insights into agricultural practices and environmental changes reflected in a late Holocene pollen record from Lake Parishan, SW Iran: Vegetation History and Archaeobotany, v. 25, p. 1-15.

Dortch, J.M., Owen, L.A., And CafFeE, M.W., 2013, Timing and climatic drivers for glaciation across semi-arid western Himalayan-Tibetan orogen: Quaternary Science Reviews, v. 78, p. 188-208.

FAIRSERVIS, W.A., 1961, Archeological Studies in the Seistan Basin of Southwestern Afghanistan and Eastern Iran: Anthropological Papers of the American Museum of Natural History, New York, p. 1-156.

Farhoudi, G., Rahnama-Rad, J., and Derakhshani, R., 2005, Morphotectonic Analysis of Chahnimeh Depressions in Sistan, Iran: Journal of Applied Geology, v. 1, p. 30-37.

Fleitmann, D., Burns, S.J., Mangini, A., Mudelsee, M., Kramers, J., Villa, I., Neff, U., Al-Subbary, A.A., Buettner, A., And Hippler, D., 2007, Holocene ITCZ and Indian monsoon dynamics recorded in stalagmites from Oman and Yemen (Socotra): Quaternary Science Reviews, v. 26, p. 170-188.

Griffiths, H.I., Schwalb, A., and Stevens, L.R., 2001, Evironmental change in southwestern Iran: the Holocene ostracod fauna of Lake Mirabad: The Holocene, v. 11, p. $757-764$.

Gupta, A.K., Anderson, D.M., And Overpeck, J.T., 2003, Abrupt changes in the Asian southwest monsoon during the Holocene and their links to the North Atlantic Ocean: Nature, v. 421, p. 354-357.

Hammarlund, D., Buörck, S., Buchardt, B., Israelson, C., and Thomsen, C.T., 2003, Rapid hydrological changes during the Holocene revealed by stable isotope records of lacustrine carbonates from Lake Igelsjön, southern Sweden: Quaternary Science Reviews, v. 22, p. 353-370.

Hamzeh, M.A., Gharaie, M.H.M., Lahijani, H.A.K., Duamali, M., Harami, R.M., and BeNI, A.N., 2016, Holocene hydrological changes in SE Iran, a key region between Indian summer monsoon and Mediterranean winter precipitation zones, as revealed from a lacustrine sequence from Lake Hamoun: Quaternary International, v. 408, p. 25-39.

IAEA, 1992, Statistical treatment of data on environmental isotopes in precipitation, Technical Report, Vienna I.A.E.A, 781 p. 
Iто, E., 2001, Application of Stable Isotope Techniquesto Inorganic and Biogenic Carbonates, in W.M. Last and J.P. Smol, Tracking Environmental Change Using Lake Sediments, Volume 2: Physical and Geochemical Methods: Kluwer Academic Publishers, Dordrecht, p. 351-371.

Jones, M., Duamali, M., Stevens, L., Heyvaert, V., Askari, H., Norolahie, D., and Weeks, L., 2011, Mid Holocene environmental and climatic change in Iran: Ancient Iran and its Neighbours, in C. Petrie (ed.), Local Developments and Long-range Interactions in the 4th Millenium BC: British Institute for Persian Studies and Oxbow Books, Oxford, UK, p. $26-35$.

JuX, U. AND KempF, E., 1971, Stauseen durch Travertinabsatz im zentralafghanischen Hochgebirge: Zeitschrift für Geomorphologie, Supplementband, v. 12, p. 107-137.

Jux, U. And KempF, K., 1983, Regional Geology of Sistan (Southwest Afghanistan): Prehistoric Sistan, v. 1, p. 5-60.

Keatings, K. and Holmes, J., 2002, The effects of diagenesis on the trace element and stable isotope geochemistry of non-marine ostracod valves: Journal of Paleolimnology, v. 28 , p. $245-252$.

KIM, S.-T. AND O’NEIL, J.R., 1997, Equilibrium and nonequilibrium oxygen isotope effects in synthetic carbonates: Geochimica et Cosmochimica Acta, v. 61, p. 3461-3475

Konert, M. and Vandenberghe, J., 1997, Comparison of laser grain size analysis with pipette and sieve analysis: a solution for the underestimation of the clay fraction: Sedimentology, v. 44, p. 523-535.

KrinsLey, D.B., 1970, A Geomorphological and Paleoclimatological Study of the Playas of Iran. Part I: DTIC Document, 370 p.

Lamberg-Karlovsky, C.C., 1968, Survey and Excavations in the Kirman Area: Iran, Technical Report, VI, p. 167-168.

LenG, M.J., 2006, Isotopes in Palaeoenvironmental Research: Springer, New York. 307 p.

Leroy, S.A., Kakroodi, A.A., Kroonenberg, S., Lahijani, H.K., Alimohammadian, H., and NigArov, A., 2013, Holocene vegetation history and sea level changes in the SE corner of the Caspian Sea: relevance to SW Asia climate: Quaternary Science Reviews, v. 70, p. $28-47$.

Leroy, S.A., López-Merino, L., Tudryn, A., Chalié, F., and Gasse, F., 2014, Late Pleistocene and Holocene palaeoenvironments in and around the middle Caspian basin as reconstructed from a deep-sea core: Quaternary Science Reviews, v. 101, p. 91-110.

Lisiecki, L.E. AND Raymo, M.E., 2005, A Pliocene-Pleistocene stack of 57 globally distributed benthic $\delta 180$ records: Paleoceanography, v. 20, p. 1-17.

Majidzadeh, Y., 2003, Jiroft: The Earliest Oriental Civilization: Printing and Publishing of the Ministry of Culture and Islamic Guidance, Tehran, p. 69-103.

Mayewski, P.A., Meeker, L.D., Twickler, M.S., Whitlow, S., Yang, Q., Lyons, W.B., And Prentice, M., 1997, Major features and forcing of high-atitude Northern Hemisphere atmospheric circulation using a 110,000-year-long glaciochemical series: Journal of Geophysical Research-Oceans, v. 102, p. 483-486.

Mayewski, P.A., Rohling, E.E., Stager, J.C., Karlén, W., Maasch, K.A., Meeker, L.D., Meyerson, E.A., Gasse, F., van Kreveld, S., and Holmgren, K., 2004, Holocene climate variability: Quaternary Research, v. 62, p. 243-255.

McKenzie, J., 1985, Carbon isotopes and productivity in the lacustrine and marine environment: Chemical Processes in Lakes, John Wiley and Sons, New York, New York, p. $99-118$

McMaнon, H., 1906, Recent survey and exploration in Seistan: The Geographical Journal, v. 28, p. 209-228.

Middleton, N., 1986, A geography of dust storms in South-West Asia: Journal of Climatology, v. 6, p. 183-196.

Miller, C.S., Leroy, S., Izon, G., Lahijani, H., Marret, F., Cundy, A., and Teasdale, P., 2013, Palynology: a tool to identify abrupt events? An example from Chabahar Bay, southern Iran: Marine Geology, v. 337, p. 195-201.

Mollashahi, N., Zarrinkoub, M., Mohammadi, S., and Khatib, M., 2011, Petrology of young volcanics in Hamun lake area (east of Iran): Iranian Journal of Crystallography and Mineralogy, v. 3, p. 519-528. (In Persian)

Munsell Color Charts, 2000, Revised washable edition: Gretag Macbeth, New Windsor, NY.

Owen, L.A. AND Dortch, J.M., 2014, Nature and timing of Quaternary glaciation in the Himalayan-Tibetan orogen: Quaternary Science Reviews, v. 88, p. 14-54.
Parker, A.G., Goudie, A.S., Stokes, S., White, K., Hodson, M.J., Manning, M., And Kennet, D., 2006, A record of Holocene climate change from lake geochemical analyses in southeastern Arabia: Quaternary Research, v. 66, p. 465-476.

PIAS, J., 1974, Pédogenèses et accumulations calcaires successives en Afghanistan au cours des quarante derniers millénaires: Comptes Rendus de l'Académie des Sciences, Série D, Sciences Naturelles, v. 278, p. 2625-2628.

Potts, D.T., Lamberg-Karlovsky, C., Pittman, H., and Kohl, P.L., 2001, Excavations at Tepe Yahya, Iran, 1967-1975: the third millennium: Peabody Museum of Archaeology, V. 45 , p. $85-146$

Reimer, P.J., Bard, E., Bayliss, A., Beck, J.W., Blackwell, P.G., Bronk Ramsey, C., Buck, C.E., Cheng, H., Edwards, R.L., And Friedrich, M., 2013, IntCal13 and Marine13 radiocarbon age calibration curves 0-50,000 years cal BP: Radiocarbon, v. 55, p. 1896 1887.

Ricketts, R.D., Johnson, T.C., Brown, E.T., Rasmussen, K.A., and Romanovsky, V.V., 2001, The Holocene paleolimnology of Lake Issyk-Kul, Kyrgyzstan: trace element and stable isotope composition of ostracodes: Palaeogeography, Palaeoclimatology, Palaeoecology, v. 176, p. 207-227.

SAID-SAJADI, S., 2000, The natural environment and historical monuments in the plain of Sistan: Geographical Research, v. 15, p. 146-186.

SAJJADI, S.M.S., 1987, Prehistoric Settlements in the Bardsir Plain, South-Eastern Iran: Eas and West, v. 1, p. 11-129.

Salvatori, S. And Vidale, M., 1982, A brief surface survey of the Protohistoric site of Shahdad (Kerman, Iran): Rivista di Archeologia VI, v. 6, p. 5-10.

Schulz, E. And Whitney, J.W., 1987, Upper Pleistocene and Holocene lakes in the An Nafud, Saudi Arabia: Paleolimnology, v. 4, p. 175-190.

Sharifi, A., Pourmand, A., Canuel, E.A., Ferer-Tyler, E., Peterson, L.C., Aichner, B. Feakins, S.J., Daryaee, T., Duamali, M., and Naderi Beni, A., 2015, Abrupt climate variability since the last deglaciation based on a high-resolution, multi-proxy peat record from NW Iran: the hand that rocked the Cradle of Civilization?: Quaternary Science Reviews, v. 123, p. 215-230.

Sirocko, F., Sarnthein, M., Erlenkeuser, H., Lange, H., Arnold, M., and Duplessy, J.C., 1993, Century-scale events in monsoonal climate over the past 24,000 years. Nature, $v$ 364 , p. $322-324$

SMITH, G.I., 1974, Quaternary deposits in southwestern Afghanistan: Quaternary Research, v. 4 , p. $39-52$.

Staubwasser, M., Sirocko, F., Grootes, P., And Segl, M., 2003, Climate change at the 4.2 ka BP termination of the Indus valley civilization and Holocene south Asian monsoon variability: Geophysical Research Letters, v. 30, p. 372-387.

Stevens, L.R. Wright, H., AND Ito, E., 2001, Proposed changes in seasonality of climate during the late glacial and Holocene at Lake Zeribar, Iran: The Holocene, v. 11, p. 747 755 .

Tosi, M., 1983, Prehistoric Sistan: Reports and Memoirs, v. 19, IsMEO, Rome.

VAN Zeist, W. and Bottema, S., 1977, Palynological investigations in western Iran: Palaeohistoria Bussum, v. 19, p. 19-85.

Vekerdy, Z., Dost, R., ReininK, G., and Partow, H., 2006, History of Environmental Change in the Sistan Basin Based on Satellite Image Analysis: 1976-2005: United Nations Environment Programme. Nairobi, Kenya. 56 p.

Wasylikowa, K., Witkowski, A., Walanus, A., Hutorowicz, A., Alexandrowicz, S.W., and LANGER, J.J., 2006, Palaeolimnology of Lake Zeribar, Iran, and its climatic implications: Quaternary Research, v. 66, p. 477-493.

Weippert, D., Wittekindt, H., and Wolfart, R., 1970, Zur geologischen Entwicklung von Zentral-und Südafghanistan: Kabul, Beihefte zum Geologischen Jahrbuch, heft 92, p. 99. Whitney, J.W., 2007, Geology, water, and wind in the Lower Helmand Basin, Southern Afghanistan: U.S. Geological Survey Scientific Investigations Report 2006-5182, Reston, Virginia, $40 \mathrm{p}$.

Williams-Sether, T., 2008, Streamflow characteristics of streams in the Helmand Basin, Afghanistan: U.S. Geological Survey Data Series 333, 341 p.

Received 30 May 2016; accepted 10 October 2016 